\section{West Germany calls for action}

Brussels

WEST Germany faces other North Sea coastal states in Bre en this week with demands to make headway in the next two years on marine pollution and insproved monitoring of the ecosystem of the valuable fishing grounds of the North Sea.

Participating in the International Conference on the Protection of the North Sea are ministers from the coastal states (Belgium, Denmark, France, the Netherlands, Norway, Sweden and the United Kingdom), from whom West Germany hopes to extract a political commitment to ratify and strengthen existing international conventions. The European Economic Community is also invited.

The North Sea is at present covered not by one but by several international conventions governing the protection of the marine environment from pollution from land-based sources (Oslo, Paris), from pollution by oil (Bonn) and from dumping (London). Not all have been ratified.

The West Germans stress the danger of latent chronic pollution (accumulation of chemicals) as well as more directly visible pollution such as oil. They are particularly concerned about the ecological sensitivity of coastal waters, river estuaries and mudflats, important feeding grounds for fish and birds.

The discharge of dangerous substances through inland and coastal waters is controlled by the 1974 Paris Convention. In 1976, the European Community also adopted a framework directive on emission standards for industrial waste discharges, but so far only limits on mercury, cadmium, polychlorinated biphenyl wastes, waste oils and lindane (last June) have been adopted, out of a list of 129 dangerous substances.

According to Greenpeace, the environmental pressure group, 1,120 tonnes of cadmium and 1,000 tonnes of mercury continue to flow annually into the North Sea. Twenty-three million tonnes of toxic sludge end up in Rotterdam harbour.

Some 11 million tonnes of largely untreated sewage sludge also end up in the North Sea, with the result that algal growth in the North Sea has increased considerably over the past 5-10 years, according to the West Germans.

The West German proposals also include a system for licensing wastes, discharges, and international information exchange on the quantities discharged and requirements that the pollution load should be reduced. At the beginning of this year, West Germany introduced a domestic system of fines for pollution of the North Sea.

According to the West Germans, there is a definite need for further action, including better enforcement and an extension of the Marpol conventions. They also propose that the North Sea be designated as a special area, that sea dumping should be reduced and eventually dropped. The European Community is preparing a directive banning the dumping of blacklisted substances and limiting others.

To combat oil pollution, West Germany proposes a region-wide system of airborne surveillance, improved cooperation in port state control, more use of deep-sea pilots' services and greater compliance by drilling rigs with rules the oil content of effluent.

West Germany also wants to extend research and development programmes to include more biological monitoring and the sampling of more substances. The Paris Commission (the secretariat of the Paris Convention) already monitors mercury, cadmium, polychlorinated biphenyls, oil

\section{Washington}

US DEPARTMENT of Agricullure (USDA) scientists working to combat the citrus canker now rampant in Florida (see Nature 27 September, p.293) are frustrated by a ban on new agricultural science exchanges with China. The US scientists were hoping to use a symposium planned for this month in China as an opportunity to collect new citrus germ plasm, possibly including canker-resistant strains. But the symposium has now been called off, and researchers are wondering whether the ban will be lifted in time to plan a visit for 1985 .

The ban was ordered a year ago by the under secretary of agriculture for interna-
Whaling

\section{Tokyo}

THE Japanese Government is to try again to persuade the United States not to retaliate if Japan breaks the whaling quotas set by the International Whaling Commission (IWC) earlier this year (see Nature 18 October, p.595). Talks will be held in Washington on 1 and 2 November between the director-general of Japan's Fisheries Agency, Hiroya Sano, and John Byrne, director of the US Department of Commerce's National Oceanic and Atmsopheric Administration. Earlier attempts to reach agreement ended in failure on 16 October.

As a result, the Japanese sperm whale coastal fishing fleet (owned by the Nihon Hogei and Nitto Hogei companies) put to sea on Friday 19 October. By the following Wednesday, however, before they had had a chance to catch a whale, the four boats were ordered to return home to give new talks a chance of success.

IWC set this year's sperm whale catch quota at zero, in the absence of agreement among the member countries. Japan,

from refineries and reception facilities and drilling platforms as well as radioactive effluent from processing plants. The Community intends to start monitoring titanium dioxide wastes next year. West Gicrmany suggests that all this information should be collected in an international database.

Community support for the West German proposals is important, if only because Community directives are binding on member states, whereas conventions enter into force only when ratified. It is therefore unfortunate that, in the case of the draft directive on accidental marine spills of oil and other dangerous substances, now under discussion, West Germany, together with Belgium, Denmark, the United Kingdom and France, feels that a Community directive is neither "necessary nor desirable".

Anna Lubinska

\title{
No canker cure from China
}

tional affairs, Daniel Amstutz, in retaliation for a Chinese decision to cul imports of US grain, breaking a contract. At the time it seemed likely that China would suffer more from a ban than the United States. The Chinese action was in turn a retaliation for US limits on textile imports.

Southwest China is believed to be the region where both citrus plants and citrus canker originated, according to Dr Jack Hearn of USDA's horticultural research laboratory at Orlando, Florida. American and Chinese scientists last year exchanged plant materials of interest, but citrus canker had not then appeared in the United States.

Tim Beardsley

\section{Japan pleads to carry on}

which had been expecting a minimum quota of 400 , vital to keeping its coastal industry going, thus considers it has been unfairly victimized by pressure from conservationists elsewhere.

The Antarctic Ocean minke whale quota was also cut, this time on a scientific recommendation, to a level that would give Japan a share amounting to 1,941 whales - some 600 fewer than the number at which Nippon Kyodo Hogei, Japan's only farseas whaling company, says it can sustain commercial operations. The company is not yet abandoning whaling, however, and its mother ship, the Dai San Nisshin Maru, set sail from Yokosuka for the Antarctic on Saturday 27 October. It hopes that an agreement can be worked out with the United States before it reaches its catch quota around next January.

If the United States stands firm, then the Packwood-Magnuson amendment will be invoked if Japanese boats break the IWC rulings. Japan's fishing quota in the United State 200-mile zone could then be cut to zero.
Alun Anderson 